\title{
Clinical and morphological features of undifferentiated monomorphous GH/TSH-secreting pituitary adenoma
}

Tanja Škorić, Mirko Koršić, Kamelija Žarković ${ }^{1}$, Vesna Plavšić, Nada Bešenski ${ }^{2}$, Ljiljana Breskovac, Zlatko Giljević and Josip Paladino ${ }^{3}$

Division of Endocrinology, Department of Internal Medicine-Rebro, ${ }^{1}$ Department of Neuropathology, ${ }^{2}$ Department of Radiology and

${ }^{3}$ Department of Neurosurgery, Clinical Hospital Center-Zagreb, School of Medicine, University of Zagreb, Zagreb, Croatia

(Correspondence should be addressed to M Koršić, Division of Endocrinology, Department of Internal Medicine-Rebro, University Hospital Center-Zagreb, School of Medicine, University of Zagreb, Kišpatićeva 12, 10000 Zagreb, Croatia)

\begin{abstract}
A 41-year-old male presented with progressive visual defects, acromegaly and hyperthyroidism. After clinical evaluation a giant GH/TSH-secreting pituitary adenoma was diagnosed. Administration of the somatostatin analog octreotide at doses of $150 \mu$ g s.c. per day inhibited the secretion of both GH and TSH. A three-week treatment with octreotide prior to surgery led to slight visual improvement and CT scan showed some new necrotic areas within the tumor mass. Transcranial surgery was performed. By immunohistochemical analyses of the adenoma tissue GH, prolactin and $\beta$-chorionic gonadotropin were detected; TSH was negative. Electron microscopy revealed an undifferentiated, monomorphous adenoma with morphological features of an acidophil stem cell adenoma such as the presence of misplaced exocytoses, fibrous bodies and mitochondrial gigantism. However, the tumor cells contained small secretory granules (up to $250 \mathrm{~nm}$ ) accumulated along the cell membrane characteristic of thyrotrope cells. Furthermore, some adenoma cells were fusiform with long cytoplasmic processes resembling thyrotropes.

Two months after the operation CT scan revealed a large residual tumor. Serum GH and TSH levels had increased again and the TSH level was even higher than before the treatment. The patient died suddenly, most probably of lethal arrhythmia. Specimens of the adenoma tissue obtained at autopsy confirmed the previous findings with the exception of positive immunostaining for TSH which was found in less than $1 \%$ of the adenoma cells.

This undifferentiated, monomorphous GH/TSH-secreting pituitary adenoma represents an entity that is unusual both in its ultrastructural features and clinical manifestations suggesting a cytogenesis from an early, undifferentiated stem cell.
\end{abstract}

European Journal of Endocrinology 140 528-537

\section{Introduction}

Growth hormone/thyrotropin (GH/TSH)-secreting pituitary adenomas are very rare (about $0.5 \%$ of all pituitary adenomas) (1-4). These plurihormonal pituitary adenomas may produce hormones from different cell types in the tumor (bimorphous or plurimorphous types) or one cell may hypersecrete more than one hormone (monomorphous type) (4-10). Only a few monomorphous GH/TSH-secreting pituitary adenomas have previously been described $(4,9,10)$. Descriptions of electron microscopical features of such adenoma cells range from thyrotrope-like to somatotrope-like, and also to acidophil stem cell adenoma-like.

Morphological characteristics, clinical behavior and the effect of octreotide therapy on undifferentiated, monomorphous GH/TSH-secreting pituitary adenomas are herein discussed.

\section{Case report}

A 41-year-old male was referred to the Department of Endocrinology, Clinical Hospital Centre Zagreb, because of progressive sight deficiency with visual field defects. The patient noticed increased size of his hands, feet and nose as well as 'swelling' of his lips over the 3-month period. He had a history of several years of alcohol abuse and severe smoking (40 cigarettes per day).

Clinical examination revealed a typical acromegalic face including deep nasolabial furrows, thick lips, broad nose and a prominent supraorbital ridge. A slight protrusion of the right bulbus and an asymmetrically enlarged thyroid gland were found. Gynecomastia was present. A lipoma $(3 \times 2 \mathrm{~cm})$ of the left subscapular region was found. The sizes of his hands and feet were increased. The skin was warm and greasy. Blood pressure was 150/ $90 \mathrm{mmHg}$ and sinus tachycardia $(120 / \mathrm{min})$ was found. 
The fasting blood glucose level was $7.5 \mathrm{mmol} / \mathrm{l}$. The serum value of triglyceride was $2.99 \mathrm{mmol} / \mathrm{l}$ (normal value $<1.8 \mathrm{mmol} / \mathrm{l})$. Antithyroglobulin and antimicrosomal antibodies were negative. Serum levels of GH and insulin-like growth factor (IGF)-I were $230 \mathrm{mIU} / \mathrm{l}$ (normal range $<0.3-14 \mathrm{mIU} / \mathrm{l}$ ) and $158.4 \mathrm{nmol} / \mathrm{l}$ (normal range 13-39 nmol/l) respectively. Serum freetri-iodothyronine $\left(\mathrm{T}_{3}\right)$ was $13.6 \mathrm{pmol} / \mathrm{l}$ (normal range $3.6-7.8 \mathrm{pmol} / \mathrm{l})$ and free thyroxine $\left(\mathrm{T}_{4}\right)$ was $37.1 \mathrm{pmol} / \mathrm{l}$ (normal range $8-23 \mathrm{pmol} / \mathrm{l}$ ). Basal concentrations of TSH in serum varied from 3.4 to $4.99 \mathrm{mIU} / \mathrm{l}$ (normal range $0.32-4.1 \mathrm{mIU} / \mathrm{l})$. Serum $\alpha$-subunit of glycoprotein hormones $(\alpha$-SU) was not measured. The serum concentration of prolactin (PRL) was $8.9 \mathrm{ng} / \mathrm{ml}$ (normal range $3.1-16.5 \mathrm{ng} / \mathrm{ml}$ ), while the concentration of $\beta$-chorionic gonadotropin $(\beta-\mathrm{CG})$ was $<0.5 \mathrm{IU} / \mathrm{l}$ (normal values $<6.15 \mathrm{IU} / \mathrm{l})$. The serum level of testosterone was $2 \mathrm{nmol} / \mathrm{l}$ (normal range $8.5-63.6 \mathrm{nmol} / \mathrm{l}$ ). An oral glucose load $(100 \mathrm{~g})$ failed to suppress plasma GH. Also GH did not respond to thyrotropin releasing hormone (TRH) stimulation $(200 \mu \mathrm{g}$ i.v. $)$. L-Dopa $(0.5 \mathrm{~g}$ p.o.) had no effect on PRL release, while TRH $(200 \mu \mathrm{g}$ i.v. $)$ did not stimulate TSH or PRL secretion.

CT scan showed a giant adenoma causing compression of the optic chiasm as well as both carotid arteries (Fig. 1). Bitemporal hemianopia was recorded with a Goldmann perimetry. Thyroid ultrasonography confirmed the presence of multiple nodularity in an enlarged gland. Echocardiography revealed moderate, asymmetric hypertrophy of the left ventricle. Systolic and diastolic functions were preserved and there was no abnormality of the valves. Bone densitometry revealed osteopenia (bone mineral density: lumbar spine, L1L $40.92 \mathrm{~g} / \mathrm{cm}^{2}$, T-score - 1.43 ; femoral neck $0.69 \mathrm{~g} /$ $\mathrm{cm}^{2}$, T-score -2.16). Clinically, a pituitary adenoma secreting $\mathrm{GH}$ and $\mathrm{TSH}$ was diagnosed.
Octreotide administered at a dose of $50 \mathrm{mg}$ s.c. 3 times a day was started and serum concentrations of $\mathrm{GH}$ and TSH were measured every $2 \mathrm{~h}$ during the 1st, 3rd and the 7 th day of therapy (Fig. 2A,B). The normalization of serum peripheral thyroid hormones was achieved after ten days of treatment (total $\mathrm{T}_{3}$ $2.2 \mathrm{nmol} / \mathrm{l}$, normal levels $1.3-2.8 \mathrm{nmol} / \mathrm{l}$; total $\mathrm{T}_{4}$ $107 \mathrm{nmol} / \mathrm{l}$, normal levels $58-161 \mathrm{nmol} / \mathrm{l})$. After a three-week treatment ( $150 \mu \mathrm{g}$ s.c. daily for 16 days and $300 \mu \mathrm{g}$ s.c. daily for the next 5 days) CT examination was performed and new necrotic areas were found within the tumor mass (Fig. 3). Also examination of the visual field revealed slight improvement of the existing defect. Transcranial surgery of a pituitary adenoma was performed.

By light microscopy, the tumor was chromophobic. Immunohistochemistry showed immunoreactivity for $\mathrm{GH}, \mathrm{PRL}$ and $\beta$-CG. Immunostaining was negative for TSH, adrenocorticotropin (ACTH), luteinizing hormone $(\mathrm{LH})$, follicle-stimulating hormone (FSH), $\beta$-LH and $\beta-$ FSH (Fig. 4A,B). Electron microscopy showed that the tumor tissue was composed of monomorphous, polygonal epithelial cells (Figs 5-7). Some adenoma cells were elongated (fusiform) with long cytoplasmic processes. The tumor cells possessed oval, hyperchromatic nuclei. Small secretory granules measuring up to $250 \mathrm{~nm}$ were mainly aligned under the plasma membrane and scanty, large secretory granules measuring $800 \mathrm{~nm}$ were found in the cytoplasm. Sparse, immature haloed secretory granules measuring $150 \mathrm{~nm}$ were also seen. Misplaced exocytoses were frequent. Fibrous bodies or aggregates of filaments were recognizable. There was an increase in the number of mitochondria that were often unusually large, had irregular cristae and contained tubular structures. Endoplasmic reticulum, mostly saccular and granular, was well developed and widely dispersed. Golgi membranes were

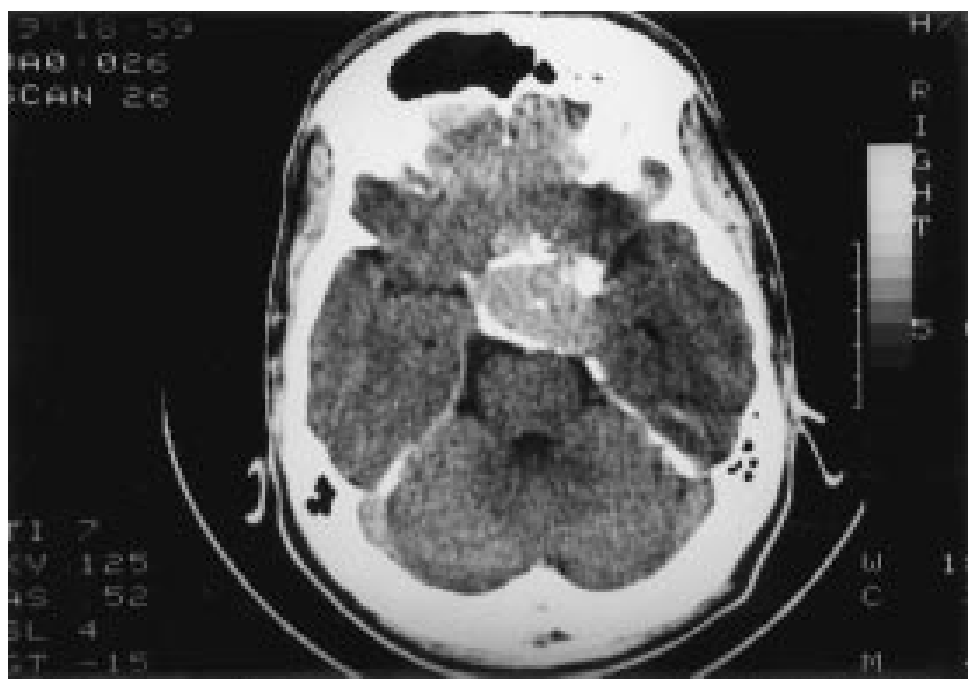

Figure 1 Transversal CT scan showing a giant, solitary adenoma measuring $5 \mathrm{~cm}$ in antero-posterior diameter. 

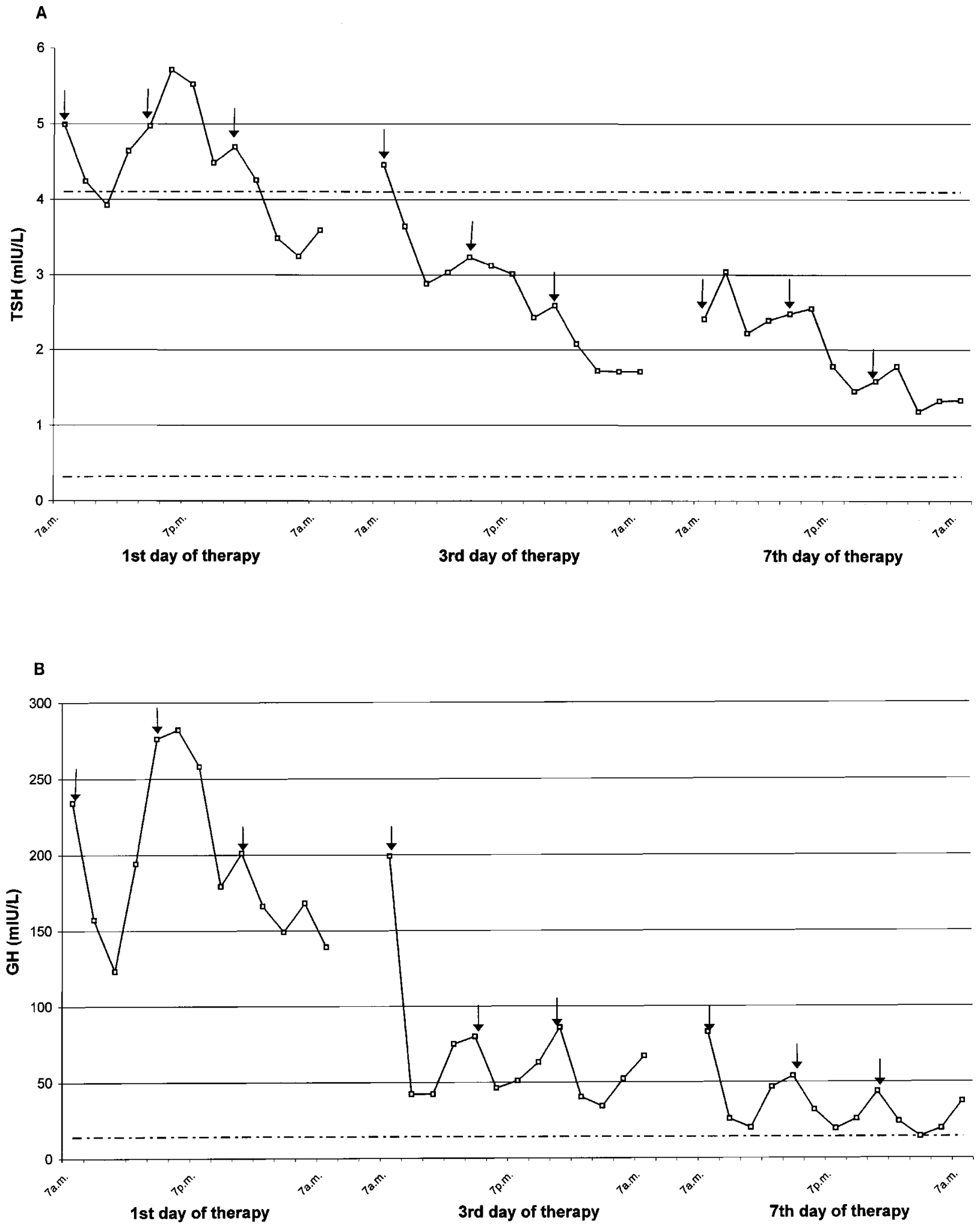

Figure 2 The levels of plasma TSH and GH over $24 \mathrm{~h}$ on the $1 \mathrm{st}$, 3rd and 7th day of treatment with octreotide $(3 \times 50 \mu \mathrm{g}$ per day). Arrows indicate the time of subcutaneous injections of octreotide. (A) Plasma TSH level (normal range $0.32-4.1 \mathrm{mIU} / \mathrm{l}$, dashed-dotted lines). (B) Plasma GH level (normal range $<0.3-14 \mathrm{mIU} / \mathrm{l}$, dashed-dotted line indicates the upper limit). 


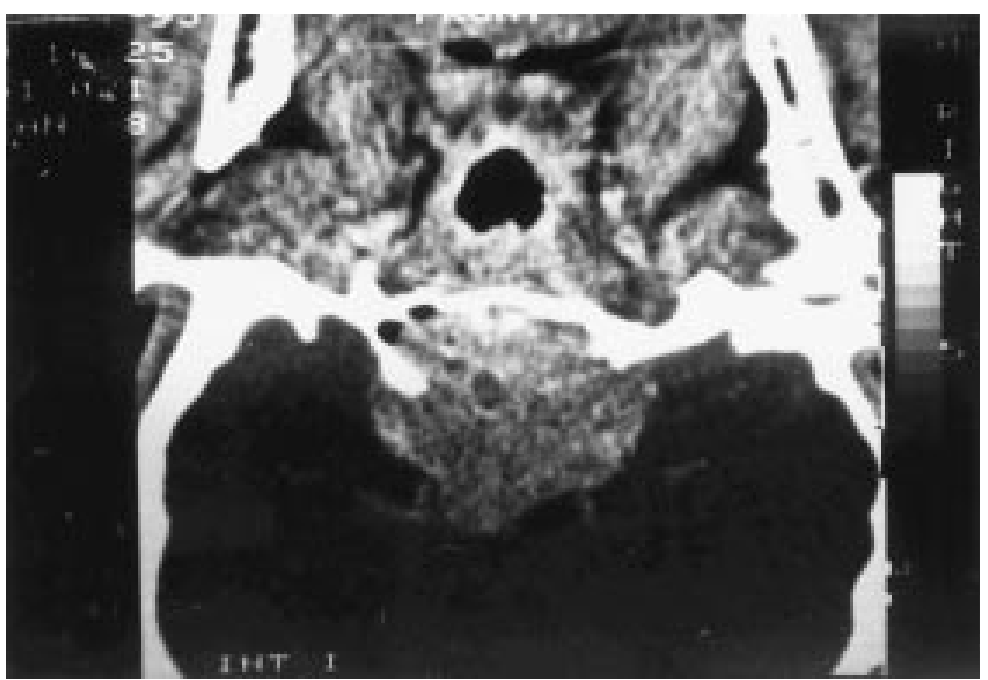

Figure $3 \mathrm{~A}$ coronal CT scan showing necrotic, hypodense areas within the tumor mass after treatment with octreotide (craniocaudal diameter of the tumor is $5 \mathrm{~cm})$. moderately developed. Sparse secondary lysosomes were found.

$\alpha$-SU was significantly increased in the pituitary adenoma cell culture (>100 IU/l, control value $0.2 \mathrm{IU} / \mathrm{l})$.

Three weeks after the operation the patient was referred to the regional Rehabilitation Centre where physiotherapy was started. During the rehabilitation an episode of thyrotoxic symptoms including diarrhea, vomiting, fever and atrial fibrillation occurred, which was misdiagnosed as acute gastroenteritis and treated with $0.9 \% \mathrm{NaCl}$ infusion and propafenon $(2 \times 150 \mathrm{mg} /$ day). Subsequent hormonal examination revealed increased serum levels of $\mathrm{GH}(35.1 \mathrm{mIU} / \mathrm{l}$, normal values $<0.3-14 \mathrm{mIU} / \mathrm{l})$ and TSH $(4.44 \mathrm{mIU} / \mathrm{l}$, normal values $0.32-4.1 \mathrm{mIU} / \mathrm{l})$. Total $\mathrm{T}_{3}$ was $6.6 \mathrm{nmol} / \mathrm{l}$ (normal range $1.3-2.8 \mathrm{nmol} / \mathrm{l}$ ), while total $\mathrm{T}_{4}$ was $315 \mathrm{nmol} / \mathrm{l}$ (normal range $58-161 \mathrm{nmol} / \mathrm{l})$. Control CT scan showed residual adenomatous tissue. The patient died suddenly, most probably of lethal arrhythmia.

At autopsy a large residual tumor $(4.5 \mathrm{~cm}$ in diameter) with destruction of the sella turcica was found. Pathohistological and immunohistochemical findings were identical to those obtained after the surgery with the exception of a few TSH-positive adenoma cells (less than $1 \%$ of cells) (Fig. 8). A renal cell carcinoma $(3.5 \mathrm{~cm}$ in diameter) of the left kidney was found. Microscopical examination of the heart revealed changes of myocardium clearly related to ischemia.

\section{Materials and methods}

\section{Hormone assays}

Serum GH was determined by immunoradiometric assay (IRMA) (Sorin-Biomedica, Saluggia, Italy). The sensitivity of the assay was $0.4 \mathrm{mIU} / \mathrm{l}$, and the intra- and interassay coefficients of variation in our laboratory were $3.9 \%$ and $9.8 \%$ respectively.

IGF-I was measured by IRMA (Diagnostic Systems Laboratory, Webster, TX, USA). The detection limit was $0.104 \mathrm{ng} / \mathrm{ml}$, and the intra- and interassay coefficients of variation were $3 \%$ and $3.7 \%$ respectively.

PRL was determined by IRMA (Diagnostic Products Corporation, Los Angeles, CA, USA). The detection limit was $0.1 \mathrm{ng} / \mathrm{ml}$, and the intra- and interassay coefficients of variation were $0.8 \%$ and $5.3 \%$ respectively.

Serum TSH levels were measured by IRMA (OrthoClinical Diagnostics, Johnson \& Johnson Company, Amersham, UK). The analytical sensitivity of the assay was $0.04 \mathrm{mIU} / \mathrm{l}$, the functional sensitivity was $0.2 \mathrm{mIU} / \mathrm{l}$ and the intra- and interassay coefficients of variation were $1.6 \%$ and $2.7 \%$ respectively.

Serum $\beta$-CG was determined by immunoenzymometric assay with luminescent substrate (IEMA) (Vitros, Johnson \& Johnson, Rochester, NY, USA). The sensitivity of the assay was $0.5 \mathrm{mIU} / \mathrm{ml}$, and the intra- and interassay coefficients of variation were $3.5 \%$ and $5.5 \%$ respectively.

Serum free (f) $\mathrm{T}_{3}$ and $\mathrm{T}_{4}$ were determined by radioimmunoassay (RIA) (DYNO-test, Henning Berlin $\mathrm{GmbH}$, Germany). Analytical sensitivity for $\mathrm{fT}_{4}$ was $1.25 \mathrm{pmol} / \mathrm{l}$, while functional sensitivity was $2.6 \mathrm{pmol} / \mathrm{l}$. Analytical sensitivity for $\mathrm{fT}_{3}$ was $0.73 \mathrm{pmol} / \mathrm{l}$, while functional sensitivity was $1.5 \mathrm{pmol} / \mathrm{l}$. The intra- and interassay coefficients of variation in our laboratory were $3.4 \%$ and $5.1 \%$ respectively for $\mathrm{fT}_{4}$, and $5.1 \%$ and $4.4 \%$ respectively for $\mathrm{fT}_{3}$.

Serum total $\mathrm{T}_{3}$ and $\mathrm{T}_{4}$ were measured by RIA (Diagnostic Products Corporation), and the detection limits were $0.1 \mathrm{nmol} / \mathrm{l}$ and $3.2 \mathrm{nmol} / \mathrm{l}$ respectively. The intra- and interassay coefficients of variation were $3.4 \%$ and $6.3 \%$ respectively for total $\mathrm{T}_{3}$, and $2.7 \%$ and $4.2 \%$ respectively for total $\mathrm{T}_{4}$. 

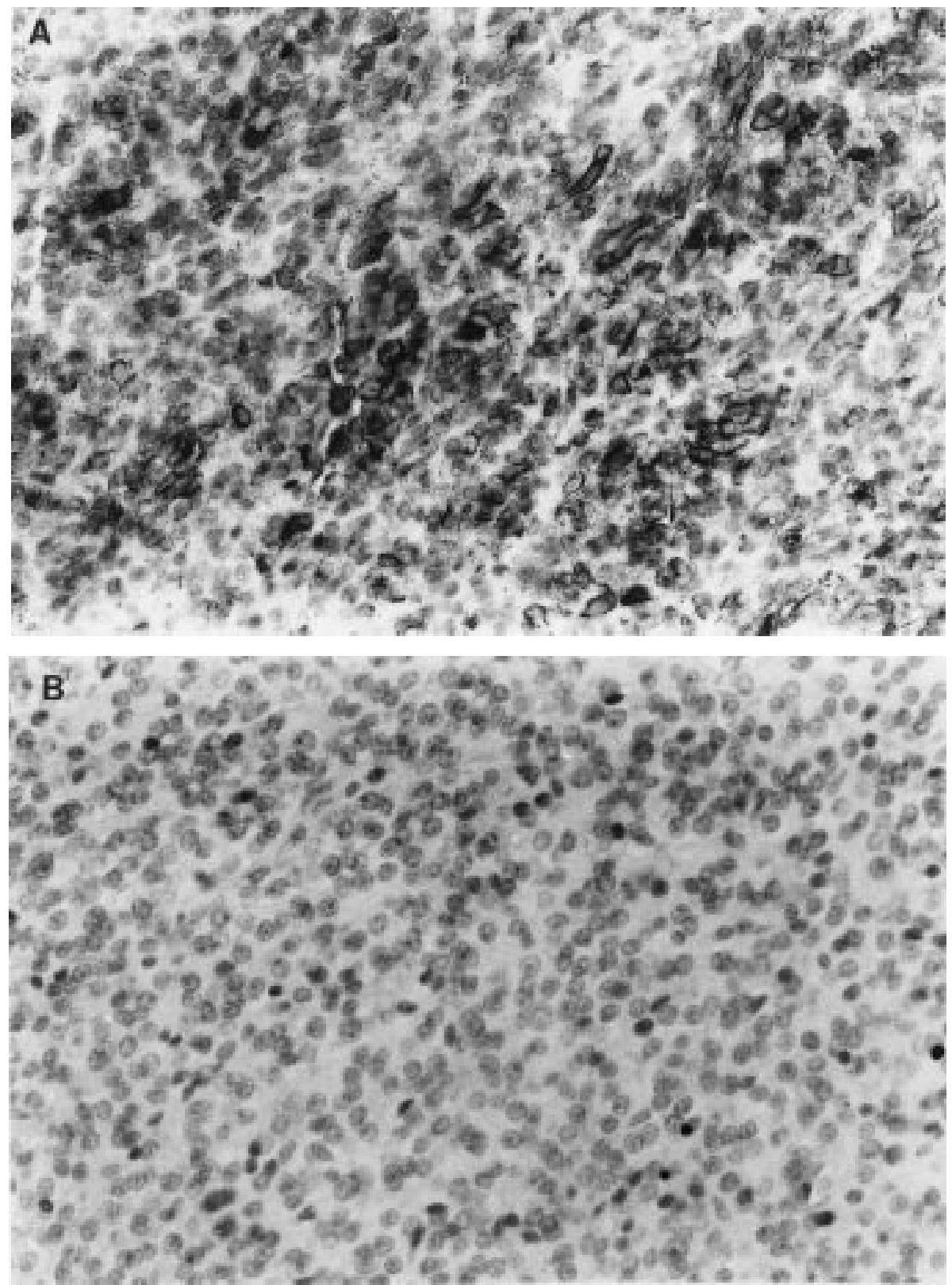

Figure 4 Immunohistochemical staining of the biopsy specimens. (A) Most of the adenoma cells show positive reaction for $\mathrm{GH}$. (B) Adenoma cells show negative reaction for TSH. PAP method, poststaining hematoxylin. Magnification $\times 400$.

$\alpha$-SU was measured by IRMA (Immunotech International, Marseille, France). The detection limit was $0.025 \mathrm{IU} / \mathrm{l}$. Intra- and interassay coefficients of variation were $6.8 \%$ and $18.6 \%$ respectively. Cross-reactions with LH, FSH and TSH were less than $0.1 \%$.

\section{Morphological studies}

For light microscopy, pieces of tumor tissue were fixed in $10 \%$ buffered formalin and embedded in paraffin. Formalin-fixed, paraffin-embedded (FFPE) sections of
$3 \mu \mathrm{m}$ thickness were stained with hematoxylin-eosin and the periodic acid Schiff method. The antigen retrieval procedure of Shi et al. (11) was used on FFPE sections before immunostaining. Primary antiserum samples were applied to detect the following hormones: GH (1:500 dilution), PRL (1:250 dilution), TSH (1:600 dilution), ACTH (1:250 dilution), LH (1:800 dilution) and FSH (1:150 dilution) (DAKO Corporation, Carpinteria, CA, USA); $\beta$-CG $(1: 200$ dilution, DAKO A/S, Glostrup, Denmark); $\beta$-LH (1:20 dilution) and $\beta$-FSH (1:50 dilution, NIDDK, Pituitary Hormones \& Antisera 


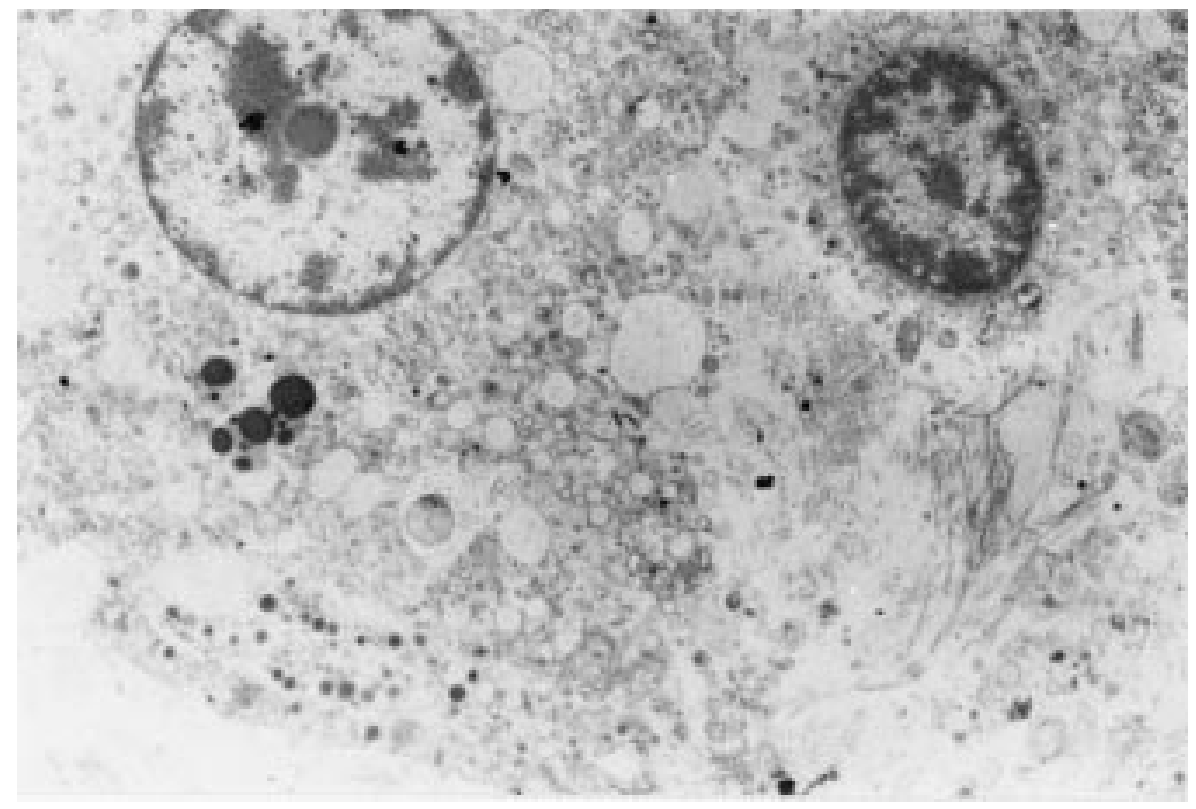

Figure 5 Sparse secretory granules accumulating along the cell membrane and an increased number of mitochondria containing irregular cristae or tubular structures are seen. Near the right nucleus a fibrous body consisting of filaments is recognizable. Magnification $\times 12250$.

Center, Harbor-UCLA Medical Center, CA, USA, donated by Dr AF Parlow). Sections were stained by the peroxidase-antiperoxidase (PAP) technique.

For electron microscopy, small pieces of tissue were fixed in $2.5 \%$ glutaraldehyde, postfixed in $1 \%$ osmium tetroxide, dehydrated, and embedded in an epoxy resin mixture (Serva, Heidelberg, Germany). Appropriate areas were selected on toluidine blue semithin sections for the ultrastructural study. Ultrathin sections (15$20 \mathrm{~nm}$ ) were stained with uranyl acetate and lead

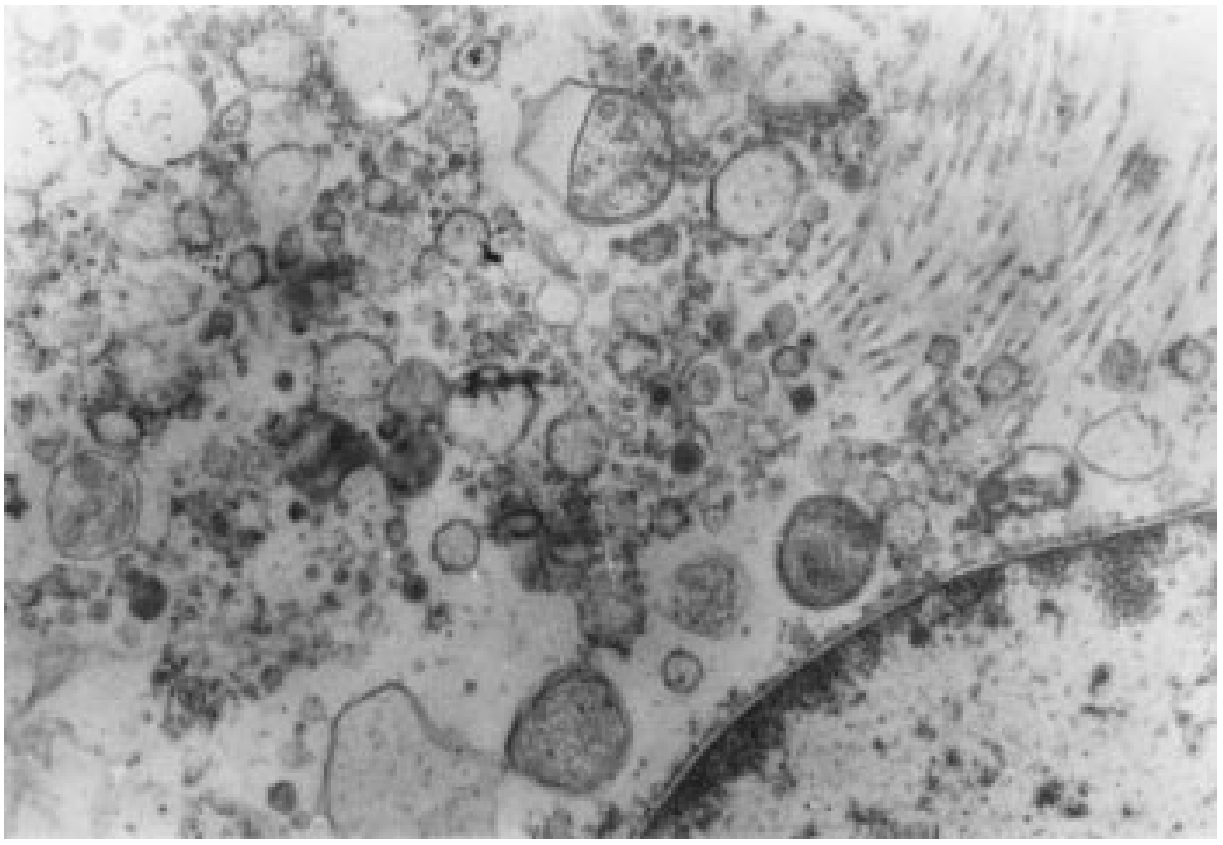

Figure 6 Near the nucleus bundles of fibrilar material are evident. Secretory granules are scant and small (up to $250 \mathrm{~nm}$ ). An increased number of mitochondria containing tubular structures (in cross section) and widely-dispersed saccular endoplasmic reticulum are seen. Magnification $\times 23750$. 


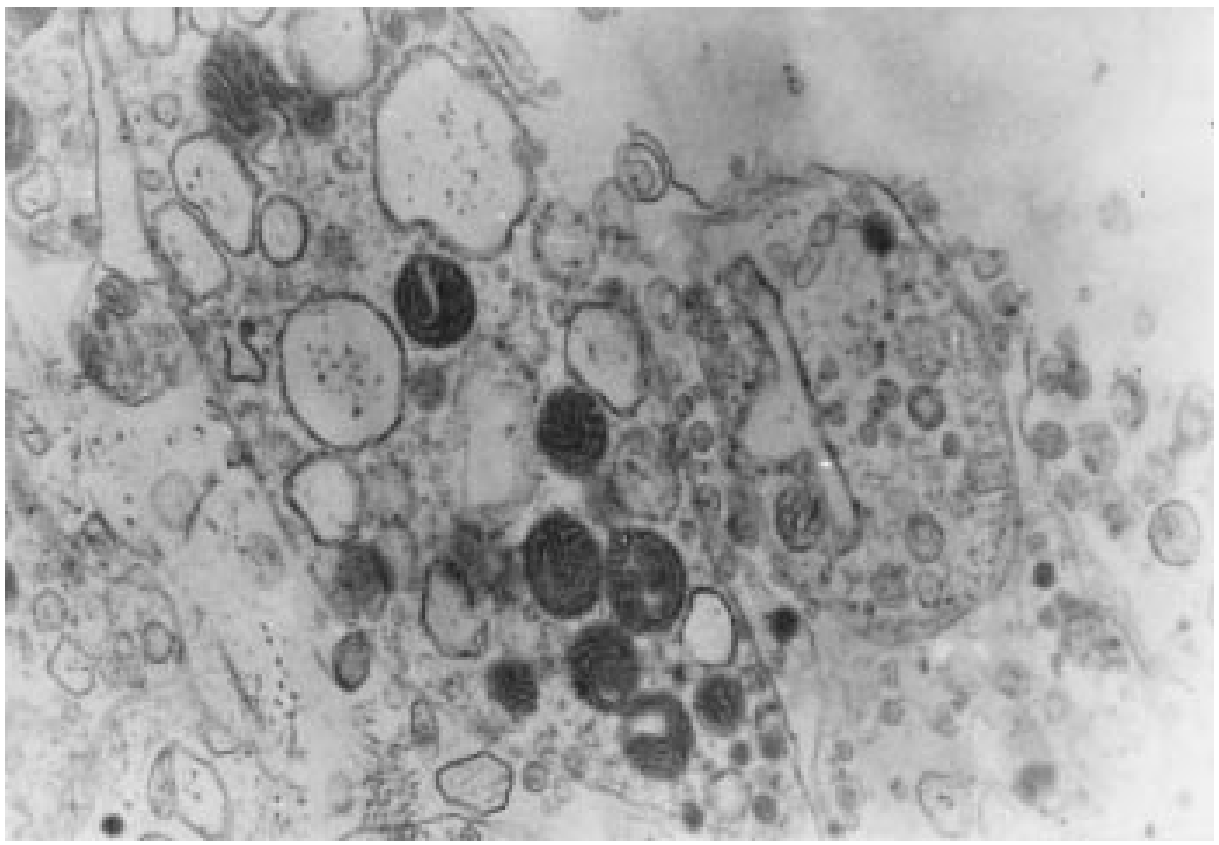

Figure 7 Mitochondria containing bizarre cristae or tubular structures. Filaments and saccular endoplasmic reticulum are widely dispersed. Magnification $\times 23750$.

citrate and examined with an electron microscope 9S-2 (Carl-Zeiss, Oberkochen, Germany).

\section{Cell culture}

Pituitary adenoma tissue was collected in iced saline at the time of surgery. The suspension was prepared under sterile conditions from mechanically and enzymatically disaggregated tissue. The number of live cells per $\mathrm{ml}$ medium was adjusted to $2 \times 10^{5}$; the cells were incubated in Dulbecco's modified Eagle's medium/ Ham's F-12 medium supplemented with $10 \%$ fetal calf serum and cultured for $72 \mathrm{~h}$ at $37^{\circ} \mathrm{C}$ in humidified air atmosphere with $5 \% \mathrm{CO}_{2}$. The same amount of medium

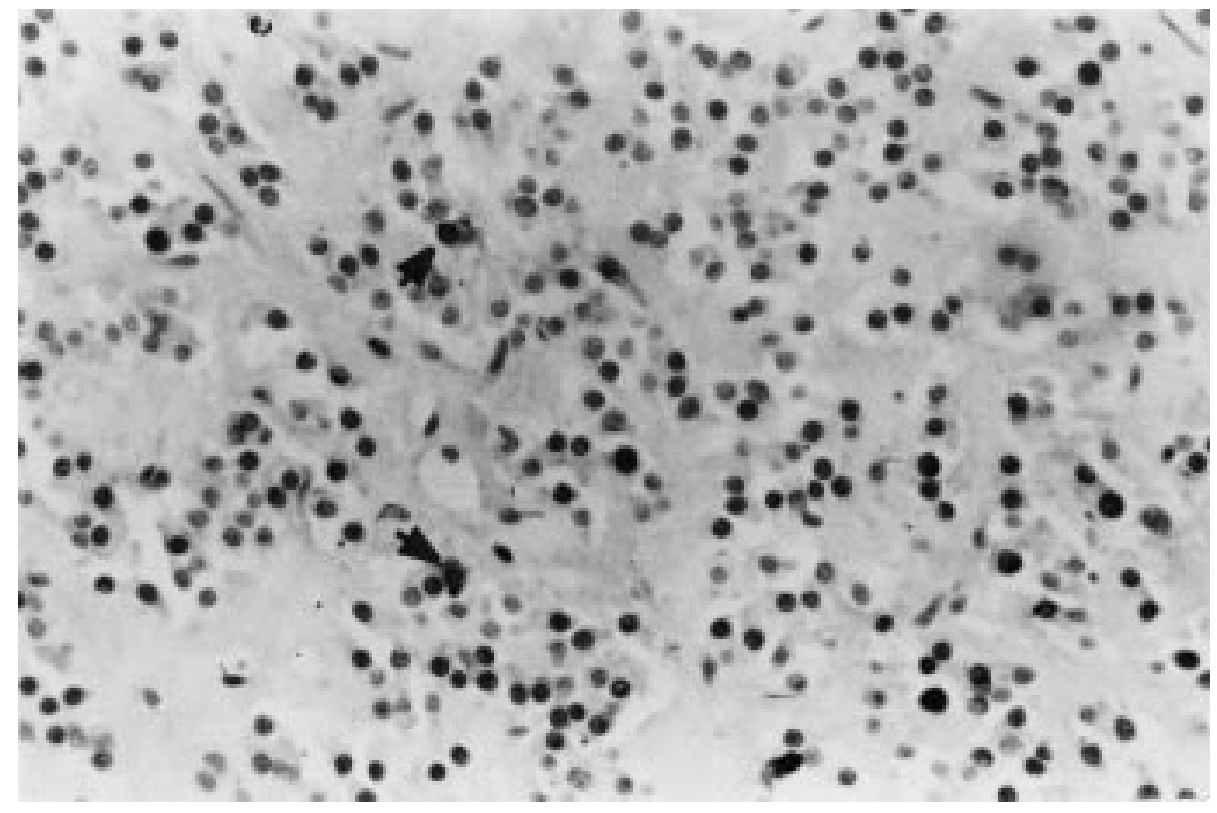

Figure $8 \mathrm{~A}$ few adenoma cells (arrows) show positive reaction for TSH in the autopsy specimen. PAP method, poststaining hematoxylin. Magnification $\times 400$ 
was incubated without pituitary tissue as the control sample. Supernatants were collected for determination of hormones (12).

\section{Discussion}

The clinical and hormonal data led to the diagnosis of a GH/TSH-secreting pituitary adenoma. Although about $60 \%$ of acromegalic patients show a paradoxical increase in GH levels following intravenous administration of $200 \mu \mathrm{g}$ TRH (13), in our patient GH did not respond to TRH. As somatostatin is known to suppress the paradoxical GH response to TRH (14), it is suggested that endogenous hypothalamic somatostatinergic activity can suppress such response in some acromegalic patients (15). The higher hypothalamic somatostatinergic activity is most probably a result of a positive feedback by GH (15). It is possible that in our patient an extremely high autonomous secretion of $\mathrm{GH}$ from the pituitary adenoma caused the increase in somatostatinergic activity. Furthermore, it seems that the enhanced endogenous somatostatinergic activity also suppressed the TRH-induced TSH response. However, other factors apart from hypothalamic somatostatinergic activity might be involved in the genesis of these responses.

Surprisingly, negative immunostaining reactions for TSH in the biopsy specimens were obtained. The absense of specific TSH immunostaining may be due to low TSH concentration in the adenomatous tissue (16). The relatively low peripheral TSH levels in the presence of a large adenomatous mass are consistent with this suggestion (17). Alternatively, masked antigen determinants on the surface of the adenomatous cells could account for the negative TSH staining (17). According to Beck-Peccoz et al., in only 5 out of 135 reported cases of all types of TSH-omas did immunostaining studies fail to show the presense of $\mathrm{TSH} \beta$, free or combined (2). However, slight TSH-positivity (less than $1 \%$ of cells) was obtained in the autopsy specimens. It is possible that tumor phenotype had changed after the operation because serum TSH levels were higher in comparison with those before the operation. On the other hand, morphological characteristics of the biopsy and autopsy tissues were identical. Immunohistochemistry for PRL and $\beta$-CG was positive, but serum levels of these hormones were within the normal range. Furthermore, PRL did not respond to TRH and dopamine. The defect in PRL and $\beta$-CG secretion may be attributed to cellular immaturity (18). The levels of $\alpha$-SU in vivo were not measured, but the concentration of $\alpha$-SU in the adenoma cell culture was significantly increased. Therefore, we assume that the pituitary adenoma secretes $\alpha$-SU in vivo. As has been documented in TSH-omas (2) and in somatotropinomas (19), $\alpha$-SU is synthesized in molar excess compared with the TSH $\beta$-subunit, which could account for in vivo and in vitro co-secretion of free $\alpha$-SU.
Electron microscopy showed that the tumor cells from the patient resembled those of an acidophilic stem cell adenoma. Monomorphous, immature cells with giant mitochondria, prominent fibrous bodies and misplaced exocytoses were diagnostic. However, the tumor cells revealed some features of thyrotropes such as the presence of small secretory granules (up to $250 \mathrm{~nm}$ ) accumulated along the cell membrane and the elongation of some cells with cytoplasmic processes. To date, few papers have appeared describing the morphological features of monomorphous GH/TSH-secreting pituitary adenomas and no consistent results have been obtained $(4,9,10)$. Clore et al. described a monomorphous adenoma containing TSH, $\alpha$-SU and GH by immunohistochemistry (9). Blood levels of TSH and $\alpha$-SU in their patient were elevated, while GH levels were normal. Electron microscopy showed welldifferentiated adenomatous thyrotropes. In addition, some adenoma cells had, within their Golgi region, mostly spherical fibrous bodies indistinguishable from those seen in sparsely granulated growth hormone cell adenomas and acidophil stem cell adenomas (9). Furthermore, Trouillas et al. reported on another two GH/TSH-secreting adenomas, which were monomorphous and resembled sparsely granulated somatotropic adenoma (4). The secretory granules measured 150$300 \mathrm{~nm}$ in diameter. Immunohistochemical reactions to TSH, GH and PRL were positive (4). These data suggest an earlier, oligopotent stem cell as the source of such neoplasms. Cells that express the transcription factor Pit-1 become committed to a cell line capable of further differentiation into either somatotropes, lactotropes, or thyrotropes (3).

The most important aspect of acidophil stem cell adenomas, as undifferentiated tumors, is their aggressive behavior. They appear to have a fast growth rate and a tendency to invade the surrounding bones. Because of their large size and occasional adhesions to neighboring tissue, their total removal may be impossible $(18,20)$. The sensitivity of an unusual GH/ PRL-secreting acidophil stem cell adenoma to somatostatin has been described previously by Page et al. (21), where combined bromocriptine $(7.5 \mathrm{mg}$ daily) plus octreotide $(100 \mu \mathrm{g}$ three times daily, s.c.) therapy suppressed GH and PRL release. We demonstrated that octreotide was able to inhibit GH and TSH secretion from a pituitary macroadenoma, causing an acute decrease in serum GH and TSH levels to $15 \%$ and $25 \%$ respectively of basal levels within 7 days of initiating therapy. Our findings were similar to those of several investigators who have previously reported on the efficacy of short and long term administration of a somatostatin analog (SMS 201995) in patients with a TSH- and/or GH-secreting pituitary adenoma $(13,22-24)$. However, it is known that in all patients in whom treatment was temporarily interrupted or permanently discountinued, serum TSH, $\alpha$-SU, and thyroid hormone levels returned to pretreatment levels (22). Furthermore, desensitization during 
long term treatment with SMS 201-995 has been reported $(2,24)$. The inhibitory effect of somatostatin on $\mathrm{GH}$ secretion from GH/TSH-secreting adenomas seems to be more permanent and without 'rebound hypersecretion' $(13,22,24)$. The same was found in our patient, whose serum TSH concentration after surgery was higher than before the octreotide and surgical treatment. Sudden death of the patient was most probably the consequence of lethal arrhythmia in thyroid crisis. Sleep apnoea as a cause of sudden death seems less probable, while no respiratory difficulties (cessations of breathing) during sleep were observed in the patient (13). Therefore, permanent postsurgical endocrine evaluation of patients with these unusual and invasive pituitary adenomas is important.

In our patient, the suppression of serum GH and TSH levels during octreotide treatment was associated with visual improvement and the appearance of some new necrotic areas within the tumor. However, necrotic areas were not found on the pathohistological examination probably due to neurosurgical procedures such as suction of necrotic parts of the tumor. A clear shrinkage of tumor mass was demonstrated in $52 \%$ of patients with TSH-secreting adenomas, while visual improvement was observed in $75 \%$ (2). On the other hand, Malarkey et al. did not find any reduction in size of a bimorphous GH/TSH-secreting adenoma after 3.5 months of therapy with SMS 201-995. Furthermore, no morphological abnormalities in the tumor were found (6). These findings raise questions about the mechanism of somatostatin action as well as somatostatin effects on cell morphology, which should be examined further $(22,26,27)$.

\section{Acknowledgements}

The authors would like to express their sincere gratitude to Prof. Beck-Peccoz for his valuable suggestions and to Dr Parlow (National Pituitary Agency, National Institutes of Health, Bethesda, USA) for providing specific $\beta$-LH antisera and reagents (AFP-3477A).

\section{References}

1 Smallridge RC. Thyrotrophinomas. In Clinical Endocrine Oncology, pp 221-224. Eds R Sheaves, PJ Jenkins \& JH Wass. Oxford: Blackwell Science Ltd, 1997.

2 Beck-Peccoz P, Brucker-Davis F, Persani L, Smallridge RC \& Weintraub BD. Thyrotropin-secreting pituitary tumors. Endocrine Reviews 199617 610-638.

3 McDermott MT \& Ridgway EC. Central hyperthyroidism. Endocrinology and Metabolism Clinics of North America 199827 187203.

4 Trouillas J, Girod C, Loras B, Claustrat B, Sassolas G, Perrin G et al. The TSH secretion in the human pituitary adenomas. Pathology Research and Practice 1988183 569-600.

5 Felix I, Asa SL, Kovacs K, Horvath E \& Smyth HS. Recurrent plurihormonal bimorphous pituitary adenoma producing growth hormone, thyrotropin, and prolactin. Archives of Pathology and Laboratory Medicine 1994118 66-70.
6 Malarkey WB, Kovacs K \& O’Dorisio TM. Response of GH- and TSH-secreting pituitary adenoma to a somatostatin analogue (SMS 201-995): evidence that GH and TSH coexist in the same cell and secretory granules. Neuroendocrinology $198949267-$ 274.

7 Kuzuya N, Inoue K, Ishibashi M, Murayama Y, Koide Y, Ito K et al. Endocrine and immunohistochemical studies on thyrotropin (TSH)-secreting pituitary adenomas: responses of TSH, $\alpha$-subunit, and growth hormone to hypothalamic releasing hormones and their distribution in adenoma cells. Journal of Clinical Endocrinology and Metabolism 199071 1103-1111.

8 Fazekas I, Pasztor E, Slowik F, Balint K, Dobronyi I, Bacsy E et al. Pathological and experimental investigations in a case of gigantism. Acta Neuropathologica 199385 167-174.

9 Clore JN, Sharpe AR, Singh Sahni K, Kovacs K \& Blackard WG. Thyrotropin-induced hyperthyroidism: evidence for common progenitor stem cell. American Journal of the Medical Sciences $19882953-5$.

10 Beck-Peccoz P, Piscitelli G, Amr S, Ballabio M, Bassetti M, Giannattasio G et al. Endocrine, biochemical and morphological studies of a pituitary adenoma secreting growth hormone, thyrotropin (TSH), and $\alpha$-subunit: evidence for secretion of TSH with increased bioactivity. Journal of Clinical Endocrinology and Metabolism 198662 704-711.

11 Shi SR, Imam SA, Young L, Cote RJ \& Taylor RJ. Antigen retrieval immunohistochemistry under the influence of $\mathrm{pH}$ using monoclonal antibodies. Journal of Histochemistry and Cytochemistry 199543 193-201.

12 Plavšić V, Koršić M, Žarković N, Rogić D, Žarković K, Giljević Z et al. Glycoprotein hormone alpha-subunit release in sera and tumor cell cultures and the responses to thyrotropin-releasing hormone in the patients with clinically nonfunctioning pituitary adenomas. Clinical Laboratory 199642 285-289.

13 Sheaves R \& Wass JAH. Acromegaly. In Clinical Endocrine Oncology, pp 195-203. Eds R Sheaves, PJ Jenkins \& JH Wass. Oxford: Blackwell Science Ltd, 1997.

14 Barkan AL, Kelch RP, Hopwood NJ \& Beitins IZ. Treatment of acromegaly with the long-acting somatostatin analog SMS 201995. Journal of Clinical Endocrinology and Metabolism $19886616-$ 23.

15 Yang I, Park S, Woo J, Kim S, Kim J, Kim Yet al. Growth hormone response to the hypothalamic somatostatinergic activity in acromegalic patients. Journal of Clinical Endocrinology and Metabolism 199782 2492-2496.

16 Koide Y, Kugai N, Kimura S, Fujita T, Kameya T, Azukizawa M et al. A case of pituitary adenoma with possible simultaneous secretion of thyrotropin and follicle stimulating hormone. Journal of Clinical Endocrinology and Metabolism 198254 397-403.

17 Savastano S, Lombardi G, Merola B, Milleto P, DiPrisco B, Manco A et al. Hyperthyroidism due to a thyroid-stimulating hormone (TSH)-secreting pituitary adenoma associated with functional hyperprolactinaemia. Acta Endocrinologica $1987116452-458$.

18 Horvath E, Kovacs K, Singer W, Smyth HS, Killinger DW, Erzin C et al. Acidophil stem cell adenoma of the human pituitary: clinicopathologic analysis of 15 cases. Cancer 198147 761-771.

19 Aylwin SJB, King A, Blenke A, Geddes JF, Wood FD, Monson JP et al. Free alpha-subunit and intact TSH secretion in vitro are closely associated in human somatotroph adenomas. European Journal of Endocrinology 1998139 378-386.

20 Marks WA, Brumback RA, Schaefer GB, Pendleton BD, Farris BK \& Culbertson JL. Acidophil stem-cell pituitary adenoma in a prepubescent female. Journal of Neurosurgery 198970 266-270.

21 Page MD, Bridges LR, Barth JH, McNichol AM \& Belchetz PE. Development of acromegaly during treatment of hyperprolactinemia with bromocriptine: an unusual acidophil stem cell adenoma. Journal of Clinical Endocrinology and Metabolism 1996 81 4484-4487.

22 Chanson PH, Weintraub BD \& Harris AG. Octreotide therapy for thyroid-stimulating hormone-secreting pituitary adenomas. Annals of Internal Medicine 1993119 236-240. 
23 Beck-Peccoz P, Mariotti S, Guillausseau PJ, Medri G, Piscitelli G, Bertoli A et al. Treatment of hyperthyroidism due to inappropriate secretion of thyrotropin with the somatostatin analogue SMS 201-995. Journal of Clinical Endocrinology and Metabolism 1989 $68208-214$.

24 Wemeau JL, Dewailly D, Leroy R, D’Herbomez M, Mazzuca M, Decoulx et al. Long term treatment with the somatostatin analogue SMS 201-995 in a patient with a thyrotropin- and growth hormone-secreting pituitary adenoma. Journal of Clinical Endocrinology and Metabolism 198866 636-639.

25 Takano K, Ajima M, Teramoto A, Hata K \& Yamashita N. Mechanisms of action of somatostatin on human TSH-secreting adenoma cells. American Journal of Physiology 1995268 E558E564.

26 Patel YC, Greenwood M, Panetta R, Hukovic N, Grigorakis S, Robertson L et al. Molecular biology of somatostatin receptor subtypes. Metabolism 199645 31-38.

27 Stevenaert A \& Beckers A. Presurgical octreotide: treatment in acromegaly. Metabolism $19964572-74$.

Received 25 November 1998

Accepted 12 February 1999 